\title{
Clinical Impact of Current Genetics Findings
}

\author{
Stephan Weidinger ${ }^{\mathrm{a}}$ Michael Kabesch ${ }^{\mathrm{b}}$
}

aDepartment of Dermatology and Allergy Biederstein, Technische Universität München (TUM), Munich, and ${ }^{b}$ Center for Pediatrics, Clinic for Pediatric Pneumology, Allergy and Neonatology, Hannover Medical School, Hannover, Germany

Atopic dermatitis (AD) is the one of the most common chronic skin diseases with prevalence rates of up to $20 \%$ in young infants and children and up to $5 \%$ in adults. The majority of patients show an onset of disease in early childhood and a spontaneous remission until adolescence, but there might be relapses, and the disease can also start in or persist into adulthood. AD presents a wide spectrum of clinical patterns and a variety of trigger factors with variable importance in the individual patient. It is frequently accompanied by elevated levels of total serum IgE antibodies and IgEmediated responses to common allergens, and often co-occurs with other allergic disorders such as food allergy, asthma and rhinitis, giving further rise to possible subpopulations of patients [1].

Since there is no objective laboratory test or histologic finding specific for $A D$, diagnosis is usually made on the basis of a dermatologic examination of skin lesions considering their age-specific morphology and distribution. Further signs leading to the diagnosis of $\mathrm{AD}$ are the chronicity of symptoms and their association with pruritus [2]. For large epidemiologic studies, numerous diagnostic criteria have been developed in order to establish a definition for $\mathrm{AD}$ by using reliable discriminators resulting in increased validity and reproducibility of the diagnosis of AD. At present, the UK diagnostic criteria are most widely validated and appear to be applicable and repeatable across all ages and many ethnicities. However, as shown in a recent review, the ideal set of diagnostic criteria still has to be established [3].

The pathophysiology of $\mathrm{AD}$ is complex and involves a disturbance of the epidermal barrier as well as abnormal immunological and inflammatory pathways leading to a Th2-dominated immune response with a Th17 component in acute AD lesions and the progressive conversion to a Th1-dominated response in chronic AD lesions [1]. 
The observation that atopic diseases tend to cluster in families has lead to the term atopic diathesis. The observation that a proportion of children with $\mathrm{AD}$ proceeds to develop allergic airway disease later in life has led to the concepts of 'atopic march', i.e. it has been suggested that $\mathrm{AD}$ is the cutaneous manifestation of 'the atopic phenotype' (as a common underlying trait) [4], and that there is a characteristic longitudinal progression of individuals through a predictable and sequential/overlapping series of phenotypes from $\mathrm{AD}$, food allergy, through allergic rhinitis and asthma [5]. However, it is notable that a significant proportion of patients with $\mathrm{AD}$ is not 'atopic', having normal total serum IgE concentrations and no specific IgE responses [6, 7]. Furthermore, recent epidemiological research indicates that sensitization might simply be a shared epiphenomenon rather than a causal factor $[6,8,9]$. In addition, the longitudinal nature of the 'atopic march' is not easily reconciled with observations made in some cohort studies which suggest that the association between asthma and $\mathrm{AD}$ may occur much earlier, i.e. early co-occurrence of $\mathrm{AD}$ and early wheezing which progresses into asthma [6]. Newly discovered mechanisms such as epidermally produced thymic stromal lymphopoietin-mediated lung inflammation may provide explanations other than allergic sensitization for an early co-association of $\mathrm{AD}$ and asthma $[10,11]$. Thus, the concepts of a common syndrome of atopic diseases and an 'allergic march' might be oversimplifications, and it appears that at least a proportion of pathophysiologic mechanisms is disease specific.

Thus, it is unclear whether $\mathrm{AD}$ is a single disorder with different clinical manifestations or a syndrome with unique or overlapping pathophysiologic pathways that coincide in a rather uniform clinical presentation. An unambiguous definition of patient subgroups is highly desirable in order to facilitate further epidemiologic, genetic and clinical investigations. Molecular studies could be of great nosological significance in that they might not only enhance our understanding of the atopic disease pathophysiology, but also enable a classification of $\mathrm{AD}$ based on the underlying genetic effects rather than on hypothetical concepts and clinical symptoms as it is the case today. A similar development already took place in other medical fields such as in neurodegenerative diseases, many of which are now defined by specific mutations in disease genes (e.g. spinocerebellar ataxias).

\section{Evidence for the Heritability of Atopic Dermatitis}

Family, twin and adoption studies have provided compelling evidence that inherited factors are of key importance in the determination of interindividual differences of susceptibility to atopic disorders, and that there is a range in phenotypic expression of this genetic predisposition [12]. Twin studies have found concordance rates for atopic dermatitis of $72-86 \%$ in monozygotic and $21-23 \%$ in dizygotic twin pairs, and segregation analyses suggested that genetic factors account for more than $70 \%$ of the variance in the susceptibility to $\mathrm{AD}$ [13-16]. As is the case for most traits of medical 
relevance, $\mathrm{AD}$ does not follow a simple Mendelian monogenic inheritance, but is considered a 'complex trait' (polygenic and multifactorial). Complex traits are the result of a complicated network of numerous susceptibility loci, many of which exert additive or synergistic effects, but have only a small role when considered in isolation [17, 18]. Among other reasons, failures to identify and replicate individual genetic risk factors for complex diseases have been attributed to epistasis (gene-by-gene interactions) obscuring the effect of single loci $[19,20]$. In addition, disease-predisposing genes interact with nongenetic environmental factors to determine the final phenotype.

\section{Approaches for Finding Atopic Dermatitis Risk Genes}

Understanding the genetic architecture of common and complex diseases is of great interest to the biomedical community. In the past few years there have been tremendous advances in molecular methods and quantitative techniques that have led to remarkable progress in complex trait genetics. However, understanding the complex networks of genes, proteins, and metabolites interacting via biochemical and physical interactions to determine the phenotype remains challenging [21].

In general, there are three types of studies that have been used to identify gene variants associated with susceptibility to $\mathrm{AD}$ : genomewide linkage scans followed by fine mapping of a linked region, candidate gene association studies, and genomewide association (GWA) studies [22]. Alternative approaches include the use of gene expression arrays, and the combination of gene expression analyses with genomewide genotyping for quantitative trait loci mapping [23]. In addition, animal models represent a useful complement to human-based genetic studies [24]. However, for $\mathrm{AD}$ so far there is no single comprehensive animal model, so that many of the disease components will have to be modeled in animals as isolated traits (and subsequently in combination) to explore pathophysiological mechanisms [25].

\section{Hints from Genomewide Studies}

Genomewide linkage studies are hypothesis-free scans comparing the transmission of genetic information with the disease within families. To this end, a relatively small set of highly polymorphic markers that cover the entire genome is investigated. While linkage studies have been very successful in mapping rare single-gene disorders, the technique has proven to be less powerful for mapping complex diseases, in which multiple low-risk genetic variants are involved. In addition, linkage regions usually extend over large distances that might contain hundreds of genes and thus require intensive follow-up fine mapping analyses [26].

To date five genomewide linkage studies have been carried out on $\mathrm{AD}$. The results from these genome screens largely differ from one another, and under a threshold 
of no more than $10 \mathrm{cM}$ distance between linkage peaks replication can only be considered for a locus on chromosome 3p24 [27, 28]. The lack of replication of linkage peaks in independent studies might be due to genetic heterogeneity or differences in ascertainment schemes and phenotype definitions, sample sizes, marker panels and analytical methods, but more likely it reflects the limitations of linkage studies for the dissection of complex traits, especially when utilized on small samples sizes. Apart from filaggrin ( $F L G$ ), which accounts for part of the significant linkage signal on 1q21 [29], the underlying disease genes for all other susceptibility loci identified by that approach remain elusive. Interestingly, regions linked to $\mathrm{AD}$ show only very limited overlap to those of asthma, suggesting that susceptibility to asthma and eczema is mediated through different genes rather than through a shared susceptibility to a common atopic background in family aggregated forms of these diseases. The AD loci identified thus far are, however, closely coincident with psoriasis susceptibility regions, e.g. 1q21, suggesting that these conditions share susceptibility loci in genomic regions encoding genes most relevant for the skin as target organ. These overlaps of associations may hint to shared and general effects of dermal inflammation, immunity and structure and to an important role for proteins expressed by epithelial cells in both diseases [30].

The advent of the genomewide association (GWA) approaches, which had become feasible through newly developed high-throughput single nucleotide polymorphisms (SNP) genotyping platforms and knowledge gained from the HapMap project, has revolutionized the discovery of genetic variants associated with complex diseases [31]. In the past years, hundreds of common low-risk variants (i.e. those that are present in more than $5 \%$ of the population and typically with ORs of 1.2-3.0) could be identified for more than 70 complex disorders and traits, which however explain only a modest proportion of heritability [32]. In general, GWA studies clearly represent a powerful new tool. However, the potential of GWA studies needs to be kept in perspective. GWA approaches present many logistical, technical and biostatistical challenges, and have several significant limitations. These limitations include false-positive and false-negative results and susceptibility to bias through incomplete coverage of SNPs in the genome, genetic and disease heterogeneity, the insensitivity to rare variants (such as FLG mutations), structural variants (such as copy-number variants), and variants in recombination hotspots, the need for the large sample sizes and follow-up investigations (to detect causal variants) and the lack of information on gene function [33]. However, GWA studies clearly have the potential to significantly advance our understanding of the genetics and pathogenetic mechanisms of complex diseases such as eczema, if the studies are performed under stringent conditions, are sufficiently powered, and are thoroughly reproduced in independent populations [34].

So far, only one GWA screen has been carried out for AD. This GWA study incorporated more than 307,000 SNP markers and 10,000 individuals from both family and case-referent panels mainly collected from Germany [35]. A robust site of 
association was identified on chromosome 11q13.5, with the strongest association observed for SNP rs7927894, which is located in an intergenic region between two annotated genes, chromosome 11 open reading frame 30 (C11orf30) and leucine rich repeat containing 32 (LRRC32) [UCSC Genome Browser, Human Genome March 2006 assembly, $259 \mathrm{http}$ //genome.ucsc.edu]. This association has recently been confirmed in another independent population of Irish pediatric AD cases [36]. Interestingly, the same risk allele (rs7927894 allele A) also showed an association with Crohn's disease in another GWA study [37]. The causative gene or gene product defined by this SNP, however, remains to be identified and functionally characterized. Within the AD GWA study, the association of four prevalent FLG null mutations with eczema could again be confirmed, a potential susceptibility SNP located within the gene encoding the filaggrin-related protein hornerin from within the EDC was found, and putative, nominally significant associations of SNPs in six additional loci were observed. Clearly, follow-up studies are needed to determine out causal variants and associated phenotypes.

GWA studies have also resulted in the identification of novel susceptibility genes for asthma (ORMDL3, CHI3L1, PDE4D, IL13-RAD50) [38-41], as well as for total IgE in the gene encoding the high-affinity receptor for IgE (FCER1A), in the STAT6 and in the IL13-RAD50 locus [42]. These genes have been replicated and functional studies have supported their relevance in asthma and atopy, whereas their potential role in eczema is not clear yet.

\section{Candidate Genes for Atopic Dermatitis}

Candidate gene association studies analyze the distribution of genetic markers, usually SNPs, in unrelated individuals (case-control and case-cohort studies) or their transmission in families (family-based design) [21]. The selection of a candidate gene for study is based upon an a priori hypothesis. These arguments may either be positional, i.e. the gene is located in a region for which linkage had been observed in prior screening studies or functional, e.g. on the basis of a specific biological hypothesis or both.

More than 100 candidate genes have been investigated for association with AD so far, and assuming publication bias there are probably more genes for which associations have been sought but failed [43]. However, these hypothesis-driven studies mostly yielded inconsistent results. Only very few associations could be replicated in at least one independent study (table 1), and the specific phenotypes found to be associated varied, possibly indicating a role for the atopic state rather than eczema per se. Furthermore, the observed effects were mostly very modest, and even for replicated genes a considerable number of negative reports exist. Common reasons for the irreproducibility of results include inappropriate selection of candidate loci and markers, small sample sizes, inadequate assessment of the trait of interest and the use 
Table 1. List of the genes and their chromosomal location that have been associated with $A D$ in at least two independent

\begin{tabular}{|c|c|c|c|c|c|c|c|}
\hline Gene & Location & Variant(s) & Phenotype(s) & Population & $\begin{array}{l}\text { Number of subjects } \\
\text { (cases:controls, } \\
\text { cases/cohort) }\end{array}$ & Association & Reference \\
\hline FLG & $1 q 21.3$ & $\begin{array}{l}\text { multiple } \\
\text { variants }\end{array}$ & $\begin{array}{l}A D \text {, extrinsic } \\
A D \text {, childhood } \\
A D \text {, adult } A D \\
A D+\text { asthma }\end{array}$ & $\begin{array}{l}\text { European, } \\
\text { European- } \\
\text { American, } \\
\text { Japanese, } \\
\text { Chinese, } \\
\text { Taiwanese }\end{array}$ & $\begin{array}{l}>6,000:>27,000 \\
>3,000 \text { families }\end{array}$ & yes & $\begin{array}{l}\text { plus }>20 \\
\text { reports } \\
\text { (reviewed } \\
\text { in [61, } \\
79] \text { ) }\end{array}$ \\
\hline \multirow[t]{6}{*}{ TLR9 } & $3 p 21.3$ & rs5743836 & $A D$ & German & 281 trios & yes & [80] \\
\hline & & rs5743836 & $A D$ & German & 202 trios & yes & [80] \\
\hline & & rs5743836 & adult $A D$ & German & $274: 252$ & no & [80] \\
\hline & & $\begin{array}{l}\text { rs187084, } \\
\text { rs352139, } \\
\text { rs352140 }\end{array}$ & $A D$ & German & 281 trios & no & {$[80]$} \\
\hline & & $\begin{array}{l}\text { rs187084, } \\
\text { rs352139, } \\
\text { rs352140 }\end{array}$ & $A D$ & German & 202 trios & no & [80] \\
\hline & & $\begin{array}{l}\text { rs187084, } \\
\text { rs5743836 }\end{array}$ & adult AD & German & $136: 129$ & no & [81] \\
\hline \multirow[t]{8}{*}{ IL13 } & $5 q 31$ & rs20541 & childhood AD & $\begin{array}{l}\text { White } \\
\text { Canadian }\end{array}$ & $52: 288$ & yes & [82] \\
\hline & & rs1800925 & $A D$ & Dutch & 238:104 & yes & [83] \\
\hline & & rs20541 & $A D$ & Japanese & 185:102 & yes & [84] \\
\hline & & rs20541 & $A D$ & German & 187:98 & yes & [85] \\
\hline & & rs1800925 & childhood AD & $\begin{array}{l}\text { White } \\
\text { Canadian }\end{array}$ & $52: 288$ & no & [82] \\
\hline & & $\begin{array}{l}\text { rs1800925, } \\
\text { rs20541 }\end{array}$ & $A D$ & Chinese & $94: 186$ & no & [86] \\
\hline & & $\begin{array}{l}\text { rs1800925, } \\
\text { rs1881457 }\end{array}$ & $A D$ & Japanese & 185:102 & no & [84] \\
\hline & & $\begin{array}{l}\text { rs1800925, } \\
\text { rs2066960, } \\
\text { rs1295686, } \\
\text { rs20541, } \\
\text { rs1295685 }\end{array}$ & childhood AD & British & $178 / 1,358$ & no & [87] \\
\hline
\end{tabular}


Table 1. Continued

\begin{tabular}{|c|c|c|c|c|c|c|c|}
\hline Gene & Location & Variant(s) & Phenotype(s) & Population & $\begin{array}{l}\text { Number of subjects } \\
\text { (cases:controls, } \\
\text { cases/cohort) }\end{array}$ & Association & Reference \\
\hline \multirow{17}{*}{$\begin{array}{l}\text { SPINK5 } \\
\text { (LEKTI) }\end{array}$} & \multirow[t]{17}{*}{$5 q 32$} & rs2287774 & asthma & Chinese & $669: 711$ & yes & [88] \\
\hline & & rs2303067 & childhood AD & British & 148 families & yes & [89] \\
\hline & & rs2303067 & childhood AD & British & 73 families & yes & [89] \\
\hline & & $\begin{array}{l}\text { rs2303067, } \\
\text { rs2303063, } \\
\text { rs2303061, } \\
\text { rs2303062, } \\
\text { rs2303066, } \\
\text { rs2303068 }\end{array}$ & $A D$ & Japanese & $124: 110$ & yes & [90] \\
\hline & & $\begin{array}{l}\text { rs } 2303067, \\
\text { rs } 2303063, \\
\text { rs } 2303064, \\
\text { rs } 17860502, \\
\text { rs } 2303070\end{array}$ & $\mathrm{AD}+$ asthma & Japanese & 41 families & yes & [91] \\
\hline & & rs2303067 & $A D$ & German & 486 trios & yes & [92] \\
\hline & & rs2303067 & $A D$ & German & 773:3992 & no & [92] \\
\hline & & rs2303067 & childhood AD & Irish/UK & 418:552 & no & [92] \\
\hline & & rs2303067 & childhood AD & UK & $1583 / 7746$ & no & [92] \\
\hline & & rs2303067 & childhood AD & German & $220 / 1161$ & no & [93] \\
\hline & & $\begin{array}{l}\text { rs2303067, } \\
\text { rs2303063, } \\
\text { rs3756688 }\end{array}$ & $\mathrm{AD}+$ asthma & Dutch & $78: 200$ & no & [94] \\
\hline & & $\begin{array}{l}\text { rs2303067, } \\
\text { rs2303063, } \\
\text { rs3756688 }\end{array}$ & $\mathrm{AD}+$ asthma & Dutch & 175 trios & no & [94] \\
\hline & & rs2303067 & $A D$ & French & $99: 102$ & no & [95] \\
\hline & & $\begin{array}{l}\text { rs2303063, } \\
\text { rs2303064 }\end{array}$ & childhood AD & British & 148 families & no & [89] \\
\hline & & $\begin{array}{l}\text { rs2303063, } \\
\text { rs2303064 }\end{array}$ & childhood AD & British & 73 families & no & [89] \\
\hline & & $\begin{array}{l}\text { rs2303063, } \\
\text { rs2303065 }\end{array}$ & $A D$ & Japanese & 124:110 & no & [90] \\
\hline & & $\begin{array}{l}\text { rs2303067, } \\
\text { rs2303064, } \\
\text { rs2303063, } \\
\text { rs2303070 }\end{array}$ & asthma & Chinese & $669: 711$ & no & [88] \\
\hline
\end{tabular}


Table 1. Continued

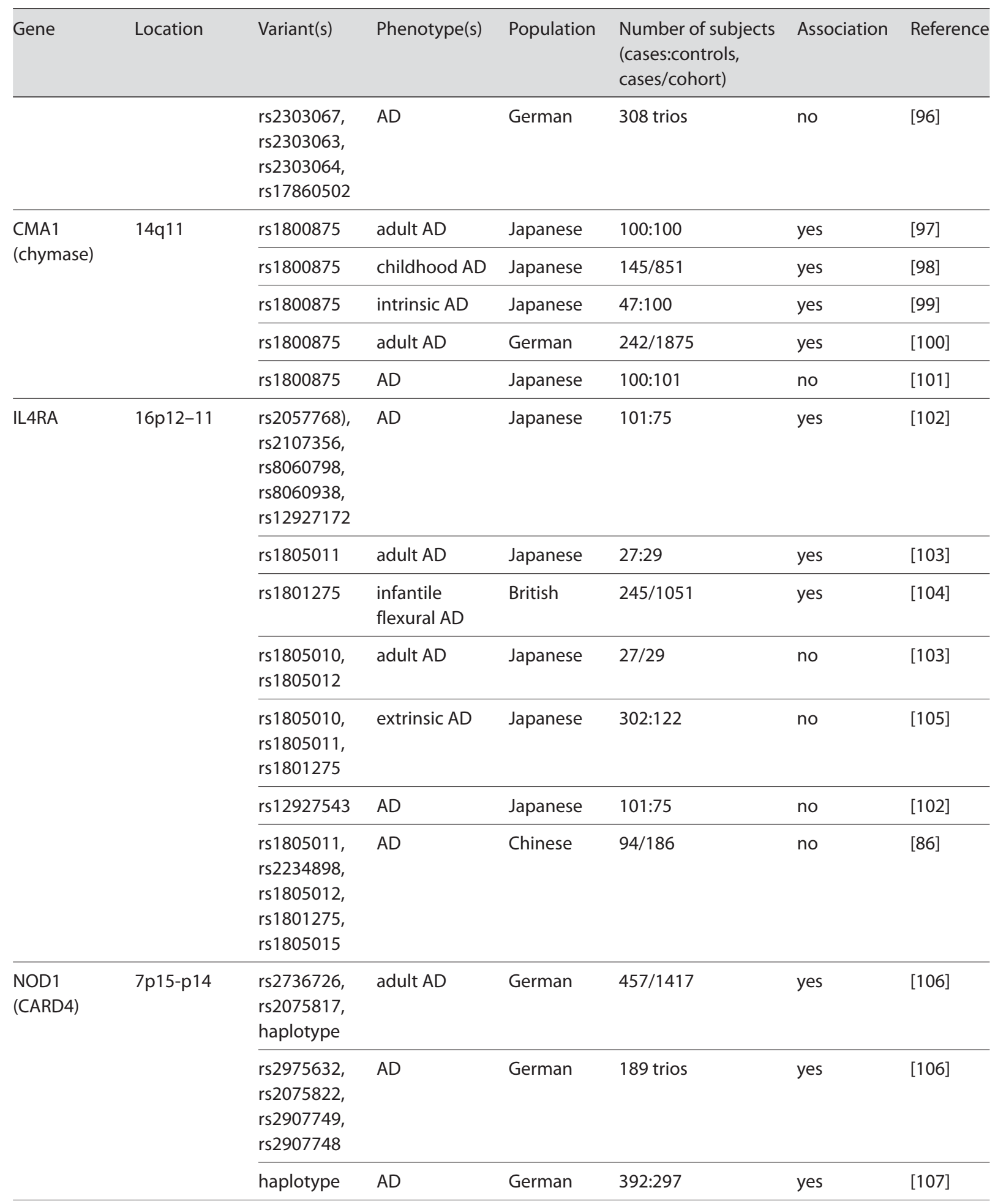


Table 1. Continued

\begin{tabular}{|c|c|c|c|c|c|c|c|}
\hline Gene & Location & Variant(s) & Phenotype(s) & Population & $\begin{array}{l}\text { Number of subjects } \\
\text { (cases:controls, } \\
\text { cases/cohort) }\end{array}$ & Association & Reference \\
\hline \multirow{4}{*}{$\begin{array}{l}\text { RANTES } \\
\text { (CCL5) }\end{array}$} & \multirow[t]{4}{*}{$17 q 11.2-q 12$} & rs2107538 & childhood AD & German & $188: 98$ & yes & [108] \\
\hline & & rs2107538 & $A D$ & Japanese & $62: 14$ & yes & [109] \\
\hline & & $\begin{array}{l}\text { rs2107538, } \\
\text { rs2280788 }\end{array}$ & extrinsic AD & Japanese & $389: 177$ & yes & [110] \\
\hline & & $\begin{array}{l}\text { rs2107538, } \\
\text { rs2280788 }\end{array}$ & $\begin{array}{l}\text { childhood } \\
\text { extrinsic AD }\end{array}$ & Hungarian & $128: 303$ & no & [111] \\
\hline
\end{tabular}

of inappropriate controls, flaws in study design and inappropriate statistical modelling, failure to replicate, and genetic and environmental heterogeneity [20].

Based on reported data, only FLG, which is presented and discussed in more detail below, appears to represent a strong and consistent $\mathrm{AD}$ risk gene across all collections in all populations and in multiple large independent studies.

\section{Filaggrin}

Among the loci linked to $\mathrm{AD}$ is the susceptibility region for psoriasis and ichthyosis vulgaris (IV), a common monogenic disorder of keratinization, on chromosome 1q21 [44], which contains the epithelial differentiation complex (EDC) [45]. The EDC is a dense cluster of genes, all of which are involved in the terminal differentiation of the keratinocytes [46]. The EDC gene filaggrin, which displays a complex highly repetitive sequence, encodes a key protein in the formation of the outermost keratin layer of the skin [47]. The large precursor of filaggrin, profilaggrin, is expressed in the keratohyalin granules of the stratum granulosum, and during formation of the cornified cell envelope it is dephosphorylated and proteolytically cleaved into the N-terminal S-100 protein and 10-12 individual filaggrin peptides [48, 49]. After cleavage, the amino-terminal domain of filaggrin enters the nucleus, where it has been suggested to have a role in regulating terminal differentiation, whereas the liberated filaggrin peptides participate in the aggregation of keratin filaments into bundles thereby promoting the flattened shape of corneocytes. Thereafter, they are released from the filaments and progressively degraded into hygroscopic amino acids and derivatives of amino acids which are believed to function as 'natural moisturizers' of the skin, which contribute to skin hydration, maintenance of skin $\mathrm{pH}$ and antimicrobial defense [50, 51]. Thus, filaggrin and its breakdown products have profound effects on skin barrier function. 


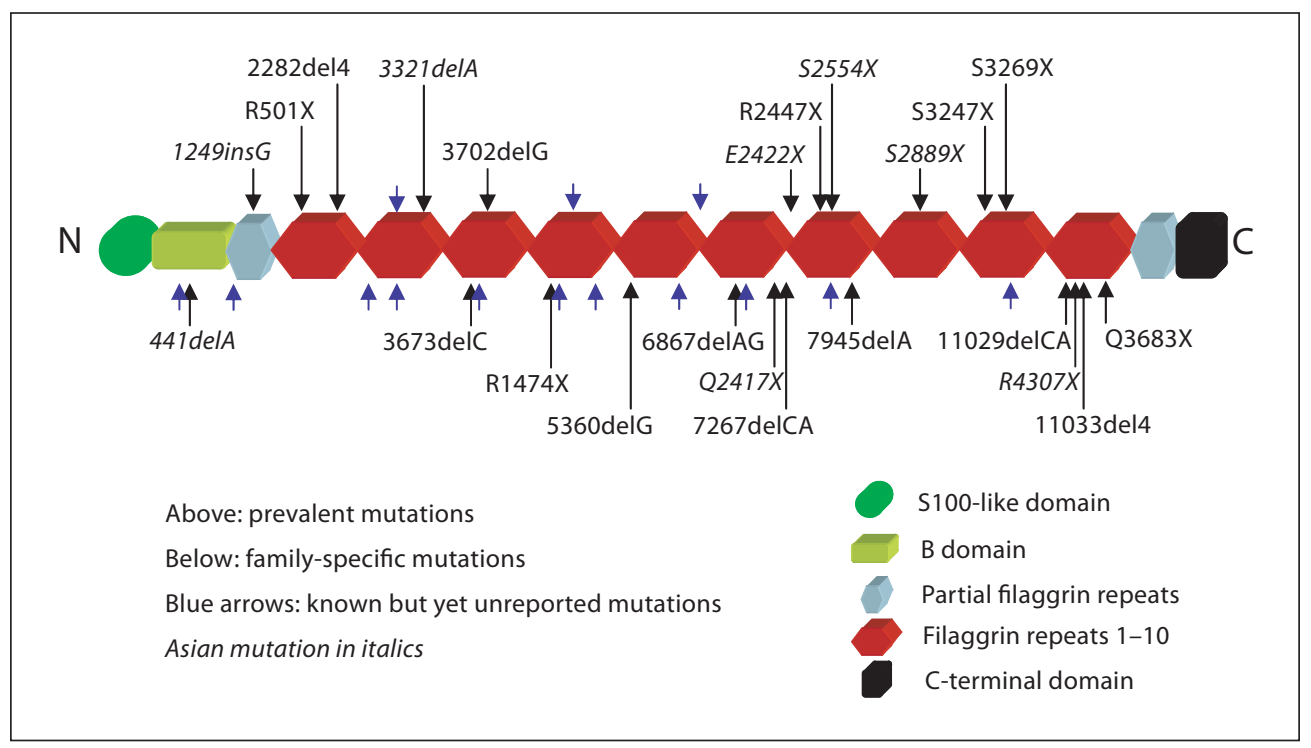

Fig. 1. Diagram of the human profilaggrin gene and domain structure. Exon 1 encodes untranslated sequence only, exon 2 contains the start codon, and the large (12,753 bp) exon 3 encodes most of the N-terminal domain and 10-12 filaggrin monomers. The position of reported loss-of-function mutations is indicated by arrows. Figure adapted from O'Regan et al. [112].

A genetically determined filaggrin deficiency was first considered to be involved in ichthyosis vulgaris, a common disease leading to an excessive scaling of the skin, and in eczema [52]. However, many confounders such as inconsistencies in the reported inheritance pattern, erroneously reported linkage, and a repetitive gene sequence limiting amplification delayed confirmation of this association until in 2006 two loss-of-function FLG mutations (R501X and 2282del4) could be identified that exhibited a semidominant pattern of inheritance with incomplete penetrance [52].

In the meantime more than 30 FLG mutations have been reported [53], seven of them common at least in one population studied $[54,55]$. Interestingly, many variants appear to be population specific, with most variants identified in populations of European ancestry, while other FLG gene mutations appear to be restricted to Asian populations [54, 56] (fig. 1). All these variants lead to frameshifts, premature stop codons, or nonsense mutations and prevent the production of free filaggrin in the epidermis. Carriers of one FLG mutation show marked reduction of FLG expression as measured by immunohistochemistry, whereas processed filaggrin is completely absent in homozygotes and compound heterozygotes [52, 54].

The well-known clinical association between IV and AD and the previously observed decrease of filaggrin expression in $\mathrm{AD}[57,58]$ suggested that FLG loss-of-function mutations might also be of relevance for AD. Subsequently, Palmer 
et al. showed that both the R501X and 2282del4 alleles are strong predisposing factors for $\mathrm{AD}$ [59]; following this initial report an impressive series of independent replication studies (for reviews, see [55, 60,61]) has provided unequivocal evidence that FLG null alleles are major risk factors for AD. These studies also indicate that FLG null alleles predispose particularly to an early-onset, severe and persistent course of $\mathrm{AD}$ with allergic sensitizations (for reviews, see [55, 62]). Remarkably, FLG null alleles are rather common with carrier frequencies of $\sim 8 \%$ in the general population and around $20 \%$ in AD cases $[61,63,64]$. In two large population-based studies $[65,66]$ it was demonstrated that, assuming causality, filaggrin mutations account for up to $15 \%$ of the total causality of all $\mathrm{AD}$ in these populations. Thus, FLG mutations are the strongest and best replicated genetic risk for $\mathrm{AD}$ to date.

FLG null alleles show an incomplete penetrance of $38.5 \%$ for the manifestation of clinically relevant AD. Recently, a strong association of FLG mutations with dry skin as an intermediate trait could be shown $[67,68]$. Thus, it seems plausible that FLG mutations primarily cause a 'dry or defective skin barrier' which, when driven by additional genetic and environmental factors, results in $\mathrm{AD}$ in a large proportion of carriers.

So far, studies on FLG mutations were primarily performed in $\mathrm{AD}$ cohorts while their role in atopic diseases independently from $\mathrm{AD}$ has not been fully determined. Several studies showed that FLG-deficient $\mathrm{AD}$ is characterized by an increased risk for allergic sensitization, elevated IgE levels, and concomitant asthma and/or allergic rhinitis (for reviews, see $[55,62]$ ). However, filaggrin is not expressed in the human bronchial mucosa [69], and so far only associations with asthma in the presence of AD and with asthma severity, but not with asthma per se, have been observed [59, 70, 71]. Thus, it has been suggested that asthma in individuals with AD could be secondary to sensitization through a primarily defective epidermal barrier $[72,73]$. This hypothesis is supported by a recent population-based study on adults which demonstrated associations of FLG mutations with 'dry skin' independent from the presence of AD, whereas associations with elevated IgE levels were only observed in atopic individuals [74]. More recent functional studies indicated that filaggrin mutations are associated with decreased levels of natural moisturizing substances, increased transepidermal water loss and increased skin $\mathrm{pH}$, whereas they do not seem to contribute to the altered ceramide profile observed in $\mathrm{AD}[75,76]$. However, more research is needed to elucidate the phenotypic characteristics caused by FLG mutations. Furthermore, the hypothesis of a 'dry or defective barrier' in FLG-mutation carriers remains to be proven [62].

Based on a post-hoc analysis of a subset of children from the German MAS birth cohort it was also claimed that the combination of FLG mutations and early sensitization to food allergens represents a remarkably strong predictor for later asthma [77]. Indeed, an easy-to-measure biomarker to identify individuals at risk for asthma before disease manifestation would be highly desirable and an obvious 
prerequisite for effective primary prevention measures. However, results from the study that was based on only a small number of infants $(\mathrm{n}=10)$ with $\mathrm{AD}, F L G$ null alleles and sensitization to food allergens who made the transition to asthma later in childhood need to be interpreted with caution. In addition, no stepwise regression method was applied and the same data was used to both develop and evaluate the predictor. Thus, independent replication and application of such a predictor to an a priori data set are needed to validate the prediction value for asthma.

\section{Clinical Impact of Genetic Findings}

Without doubt, the identification of risk genes for $\mathrm{AD}$ is of great importance to increase our knowledge of its pathophysiologic mechanisms. Genetics will help to critically review our current concepts of diagnosis and treatment of $\mathrm{AD}$ and help to develop more effective approaches.

Despite much effort and progress over the past 2 decades, our understanding of the complex genetic susceptibility to AD remains in the early stages, as it is the case for other complex diseases. Major barriers to progress are the high phenotype variability of $\mathrm{AD}$, its incomplete penetrance and its modification through environmental influences. Based on reported data, only FLG appears to clearly convey a strong and consistent $\mathrm{AD}$ risk across populations and in multiple large independent studies. Most other candidate genes for AD show inconsistent replication patterns. Data on the recently identified AD susceptibility gene from chromosome 11 identified by a GWA study [35] has not yet been replicated sufficiently to judge its relevance and robustness.

There is a need for further large-scale and whole genome studies both to clarify the roles of currently suggested candidate genes and to identify additional novel susceptibility loci. For AD, gathering data through genomewide approaches is still at an early stage and, in general, the ability to interpret genomic data accurately, evaluate their clinical utility, and use them to develop new prevention or treatment measures will require much effort in the future.

GWA studies for complex diseases so far mostly identified variants with small effects explaining only a small proportion of disease susceptibility. Nevertheless, such variants might well help to identify new and specific disease pathways and help to develop treatments that act on those pathways in individual patients.

The best example for this to date is the association of filaggrin with AD. Filaggrin deficiency seems to cause a frequent subtype of $\mathrm{AD}$ which develops on the basis of a mutation in the FLG gene ('single-gene subtypes') and not because of the predisposing effects of multiple genes and interacting environmental factors, This subtype of $\mathrm{AD}$ might require different treatments and potentially different preventive strategies. Since most of the FLG mutations identified thus far cause premature 
stop codons, novel treatment approaches based on molecular modulation of transcription activity recently identified to work in numerous genes could also be applied to filaggrin deficiency to enhance the gene's expression [78]. Further investigations on the precise characteristics and factors influencing penetrance of the FLG-related AD type will help to distinguish it from other forms of $\mathrm{AD}$. If a special FLG-related subtype of $\mathrm{AD}$ can be defined early, a precise molecular diagnosis made in a patient might help to influence the course of the disease specifically and also enable a more reliable prediction of disease risk and appropriate treatment for the patient's offspring and relatives. With ongoing research and novel genetic techniques such as whole genome sequencing, further subphenotypes of $\mathrm{AD}$ may be identified by genetics and the AD syndrome will be replaced by defined molecular diagnoses.

However, much remains to be done before genetic findings can finally be translated into an improved classification and the development of new and more targeted interventions. True causal variants need to be identified, functionally characterized and considered in interaction with each other and with environmental influences. Other sources of genetic variation such as copy number variation and epigenetic changes must be explored, and more holistic approaches integrating phenotypic variables and information from genomic, transcriptional, proteomic, metabolomic (and other) sources will be needed. Traditional phenotype definitions will have to be revisited based on familial components, heritable endophenotypes, and genetic markers. Although much has already been discovered, much remains to be learned about how the genome influences $\mathrm{AD}$ risk and pathobiology. The awaited era of genomics in personalized medicine is not yet here, but a glimpse into the potential future of molecular medicine can already be gained.

\section{References}

1 Bieber T: Atopic dermatitis. N Engl J Med 2008;358: 1483-1494.

5 Spergel JM: Atopic march: link to upper airways. Curr Opin Allergy Clin Immunol 2005;5:17-21.

2 Weidinger S, Ring J: Diagnosis of atopic eczema; in Ruzicka T, Ring J, Przybilla B (eds). Handbook of Atopic Eczema. Berlin, Springer, 2006, pp 84-97.

-3 Brenninkmeijer EE, Schram ME, Leeflang MM, Bos JD, Spuls PI: Diagnostic criteria for atopic dermatitis: a systematic review. Br J Dermatol 2008;158:754765 .

4 Johansson SG, Bieber T, Dahl R, Friedmann PS, Lanier BQ, Lockey RF, Motala C, Ortega Martell JA, Platts-Mills TA, Ring J, Thien F, Van Cauwenberge P, Williams HC: Revised nomenclature for allergy for global use: report of the nomenclature review committee of the World Allergy Organization, October 2003. J Allergy Clin Immunol 2004;113: 832-836.

6 Illi S, von Mutius E, Lau S, Nickel R, Gruber C, Niggemann B, Wahn U: The natural course of atopic dermatitis from birth to age 7 years and the association with asthma. J Allergy Clin Immunol 2004;113: 925-931.

7 Novak N, Bieber T: Allergic and nonallergic forms of atopic diseases. J Allergy Clin Immunol 2003;112: 252-262.

8 Flohr C, Weiland SK, Weinmayr G, Bjorksten B, Braback L, Brunekreef B, Buchele G, Clausen M, Cookson WO, von Mutius E, Strachan DP, Williams HC: The role of atopic sensitization in flexural eczema: findings from the international study of asthma and allergies in childhood phase two. J Allergy Clin Immunol 2008;121:141-147 e144. 
-9 Williams H, Flohr C: How epidemiology has challenged 3 prevailing concepts about atopic dermatitis. J Allergy Clin Immunol 2006;118:209-213.

$\checkmark 10$ He R, Oyoshi MK, Garibyan L, Kumar L, Ziegler SF, Geha RS: TSLP acts on infiltrating effector t cells to drive allergic skin inflammation. Proc Natl Acad Sci U S A 2008;105:11875-11880.

-11 Demehri S, Morimoto M, Holtzman MJ, Kopan R: Skin-derived TSLP triggers progression from epidermal-barrier defects to asthma. PLoS Biol 2009; 7:e1000067.

12 Morar N, Willis-Owen SA, Moffatt MF, Cookson WO: The genetics of atopic dermatitis. J Allergy Clin Immunol 2006;118:24-34; quiz 35-26.

13 Schultz Larsen F: Atopic dermatitis: a geneticepidemiologic study in a population-based twin sample. J Am Acad Dermatol 1993;28:719-723.

14 Larsen FS, Holm NV, Henningsen K: Atopic dermatitis: a genetic-epidemiologic study in a populationbased twin sample. J Am Acad Dermatol 1986;15: 487-494.

15 Thomsen SF, Ulrik CS, Kyvik KO, Hjelmborg JB, Skadhauge LR, Steffensen I, Backer V: Importance of genetic factors in the etiology of atopic dermatitis: A twin study. Allergy Asthma Proc 2007;28:535539.

16 van Beijsterveldt CE, Boomsma DI: Genetics of parentally reported asthma, eczema and rhinitis in 5-year-old twins. Eur Respir J 2007;29:516-521.

17 Moore JH: A global view of epistasis. Nat Genet 2005;37:13-14.

18 Phillips PC: Epistasis - the essential role of gene interactions in the structure and evolution of genetic systems. Nat Rev Genet 2008;9:855-867.

19 Carlborg O, Haley CS: Epistasis: too often neglected in complex trait studies? Nat Rev Genet 2004;5:618625.

-20 Cardon LR, Bell JI: Association study designs for complex diseases. Nat Rev Genet 2001;2:91-99.

21 Altshuler D, Daly MJ, Lander ES: Genetic mapping in human disease. Science 2008;322:881-888.

22 Brown SJ, McLean WH: Eczema genetics: current state of knowledge and future goals. J Invest Dermatol 2009;129:543-552.

23 Cookson W, Liang L, Abecasis G, Moffatt M, Lathrop M: Mapping complex disease traits with global gene expression. Nat Rev Genet 2009;10:184194.

24 Hunter KW, Crawford NP: The future of mouse Qtl mapping to diagnose disease in mice in the age of whole-genome association studies. Annu Rev Genet 2008;42:131-141.

25 Scharschmidt TC, Segre JA: Modeling atopic dermatitis with increasingly complex mouse models. J Invest Dermatol 2008;128:1061-1064.
26 Risch NJ: Searching for genetic determinants in the new millennium. Nature 2000;405:847-856.

27 Bradley M, Soderhall C, Luthman H, Wahlgren CF, Kockum I, Nordenskjold M: Susceptibility loci for atopic dermatitis on chromosomes 3, 13, 15, 17 and 18 in a swedish population. Hum Mol Genet 2002;11:1539-1548.

28 Haagerup A, Bjerke T, Schiotz PO, Dahl R, Binderup HG, Tan Q, Kruse TA: Atopic dermatitis - a total genome-scan for susceptibility genes. Acta Derm Venereol 2004;84:346-352.

29 Morar N, Cookson WO, Harper JI, Moffatt MF: Filaggrin mutations in children with severe atopic dermatitis. J Invest Dermatol 2007;127:1667-1672.

30 Willis-Owen SA, Morar N, Willis-Owen CA: Atopic dermatitis: insights from linkage overlap and disease co-morbidity. Expert Rev Mol Med 2007;9:113.

31 McCarthy MI, Abecasis GR, Cardon LR, Goldstein DB, Little J, Ioannidis JP, Hirschhorn JN: Genomewide association studies for complex traits: Consensus, uncertainty and challenges. Nat Rev Genet 2008;9:356-369.

32 Manolio TA, Brooks LD, Collins FS: A hapmap harvest of insights into the genetics of common disease. J Clin Invest 2008;118:1590-1605.

33 Frazer KA, Murray SS, Schork NJ, Topol EJ: Human genetic variation and its contribution to complex traits. Nat Rev Genet 2009;10:241-251.

34 Hardy J, Singleton A: Genomewide association studies and human disease. N Engl J Med 2009;360: 1759-1768.

35 Esparza-Gordillo J, Weidinger S, Folster-Holst R, et al: A common variant on chromosome $11 \mathrm{q} 13$ is associated with atopic dermatitis. Nat Genet 2009; 41:596-601.

36 O'Regan GM, Campbell LE, Cordell HJ, Irvine AD, McLean WH, Brown SJ: Chromosome 11q13.5 variant associated with childhood eczema: an effect supplementary to filaggrin mutations. J Allergy Clin Immunol;125:170-174 e171-172.

37 Barrett JC, Hansoul S, Nicolae DL, et al: Genomewide association defines more than 30 distinct susceptibility loci for crohn's disease. Nat Genet 2008;40:955-962.

38 Moffatt MF, Kabesch M, Liang L, et al: Genetic variants regulating ormdl3 expression contribute to the risk of childhood asthma. Nature 2007;448:470473.

39 Ober C, Tan Z, Sun Y, Possick JD, Pan L, Nicolae R, Radford S, Parry RR, Heinzmann A, Deichmann KA, Lester LA, Gern JE, Lemanske RF Jr, Nicolae DL, Elias JA, Chupp GL: Effect of variation in chi311 on serum ykl-40 level, risk of asthma, and lung function. N Engl J Med 2008;358:1682-1691. 
40 Himes BE, Hunninghake GM, Baurley JW, et al: Genome-wide association analysis identifies pde4d as an asthma-susceptibility gene. Am J Hum Genet 2009;84:581-593.

-41 Li X, Howard TD, Zheng SL, Haselkorn T, Peters SP, Meyers DA, Bleecker ER: Genome-wide association study of asthma identifies Rad50-il13 and Hla-Dr/ Dq regions. J Allergy Clin Immunol 2010;125:328335 e311.

42 Weidinger S, Gieger C, Rodriguez E, et al: Genomewide scan on total serum ige levels identifies fcerla as novel susceptibility locus. PLoS Genetics 2008;4:e1000166.

43 Barnes KC: An update on the genetics of atopic dermatitis: scratching the surface in 2009. J Allergy Clin Immunol 2010;125:16-29 e11-11; quiz 30-11.

44 Walley AJ, Chavanas S, Moffatt MF, Esnouf RM, Ubhi B, Lawrence R, Wong K, Abecasis GR, Jones EY, Harper JI, Hovnanian A, Cookson WO: Gene polymorphism in netherton and common atopic disease. Nat Genet 2001;29:175-178.

45 Mischke D, Korge BP, Marenholz I, Volz A, Ziegler A: Genes encoding structural proteins of epidermal cornification and s100 calcium-binding proteins form a gene complex ('epidermal differentiation complex') on human chromosome 1q21. J Invest Dermatol 1996:989-992.

\6 Toulza E, Mattiuzzo NR, Galliano MF, Jonca N, Dossat C, Jacob D, de Daruvar A, Wincker P, Serre G, Guerrin M: Large-scale identification of human genes implicated in epidermal barrier function. Genome Biol 2007;8:R107.

47 Candi E, Schmidt R, Melino G: The cornified envelope: a model of cell death in the skin. Nat Rev Mol Cell Biol 2005;6:328-340.

-48 Presland RB, Kimball JR, Kautsky MB, Lewis SP, Lo CY, Dale BA: Evidence for specific proteolytic cleavage of the $\mathrm{N}$-terminal domain of human profilaggrin during epidermal differentiation. J Invest Dermatol 1997;108:170-178.

49 Resing KA, Walsh KA, Dale BA: Identification of two intermediates during processing of profilaggrin to filaggrin in neonatal mouse epidermis. J Cell Biol 1984;99:1372-1378.

-50 Scott IR, Harding CR, Barrett JG: Histidine-rich protein of the keratohyalin granules. Source of the free amino acids, urocanic acid and pyrrolidone carboxylic acid in the stratum corneum. Biochim Biophys Acta 1982;719:110-117.

51 Rawlings AV, Harding CR: Moisturization and skin barrier function. Dermatol Ther 2004;17(suppl 1):43-48.

52 Smith FJ, Irvine AD, Terron-Kwiatkowski A, et al: Loss-of-function mutations in the gene encoding filaggrin cause ichthyosis vulgaris. Nat Genet 2006; 38:337-342.
53 O'Reagan G, Irvine AD, Chen $\mathrm{H}$, Nomura I, Campbell LE, Zhao G, Liao H, Palmer CN, Smith FJ, McLean WH, Sandilands A: The genetic architecture and population genetics of filaggrin-related atopic dermatitis, international investigative dermatology meeting, Kyoto. J Invest Dermatol 2008;128

54 Sandilands A, Terron-Kwiatkowski A, Hull PR, et al: Comprehensive analysis of the gene encoding filaggrin uncovers prevalent and rare mutations in ichthyosis vulgaris and atopic eczema. Nat Genet 2007;39:650-654.

55 Rodriguez E, Illig T, Weidinger S: Filaggrin loss-offunction mutations and association with allergic diseases. Pharmacogenomics 2008;9:399-413.

56 Nomura T, Sandilands A, Akiyama M, Liao H, Evans AT, Sakai K, Ota M, Sugiura H, Yamamoto K, Sato H, Palmer CN, Smith FJ, McLean WH, Shimizu $\mathrm{H}$ : Unique mutations in the filaggrin gene in Japanese patients with ichthyosis vulgaris and atopic dermatitis. J Allergy Clin Immunol 2007;119:434440.

57 Sugiura H, Ebise H, Tazawa T, Tanaka K, Sugiura Y, Uehara M, Kikuchi K, Kimura T: Large-scale DNA microarray analysis of atopic skin lesions shows overexpression of an epidermal differentiation gene cluster in the alternative pathway and lack of protective gene expression in the cornified envelope. $\mathrm{Br}$ J Dermatol 2005;152:146-149.

58 Seguchi T, Cui CY, Kusuda S, Takahashi M, Aisu K, Tezuka T: Decreased expression of filaggrin in atopic skin. Arch Dermatol Res 1996;288:442-446.

59 Palmer CN, Irvine AD, Terron-Kwiatkowski A, et al: Common loss-of-function variants of the epidermal barrier protein filaggrin are a major predisposing factor for atopic dermatitis. Nat Genet 2006;38: 441-446.

60 Baurecht H, Irvine AD, Novak N, Illig T, Buhler B, Ring J, Wagenpfeil S, Weidinger S: Toward a major risk factor for atopic eczema: Meta-analysis of filaggrin polymorphism data. J Allergy Clin Immunol 2007;120:1406-1412.

61 Rodriguez E, Baurecht H, Herberich E, Wagenpfeil S, Brown SJ, Cordell HJ, Irvine AD, S W: Meta analysis of filaggrin polymorphisms in eczema and asthma: robust risk factors in atopic disease J Allergy Clin Immunol 2009;subm

62 Irvine $\mathrm{AD}$ : Fleshing out filaggrin phenotypes. J Invest Dermatol 2007;127:504-507.

63 Baurecht H, Irvine AD, Novak N, Illig T, Buhler B, Ring J, Wagenpfeil S, Weidinger S: Towards a major risk factor for atopic eczema: meta-analysis of filaggrin mutation data. J Allergy Clin Immunol 2007; 120:1406-1412. 
64 Sandilands A, Smith FJ, Irvine AD, McLean WH: Filaggrin's fuller figure: a glimpse into the genetic architecture of atopic dermatitis. J Invest Dermatol 2007;127:1282-1284.

65 Henderson J, Northstone K, Lee SP, Liao H, Zhao Y, Pembrey M, Mukhopadhyay S, Smith GD, Palmer $\mathrm{CN}$, McLean WH, Irvine AD: The burden of disease associated with filaggrin mutations: a populationbased, longitudinal birth cohort study. J Allergy Clin Immunol 2008;121:872-877 e879.

-66 Weidinger S, O’Sullivan M, Illig T, Baurecht H, Depner M, Rodriguez E, Ruether A, Klopp N, Vogelberg C, Weiland SK, McLean WH, von Mutius $\mathrm{E}$, Irvine $\mathrm{AD}$, Kabesch $\mathrm{M}$ : Filaggrin mutations, atopic eczema, hay fever, and asthma in children. J Allergy Clin Immunol 2008;121:1203-1209, e1201.

67 Novak N, Baurecht H, Schafer T, Rodriguez E, Wagenpfeil S, Klopp N, Heinrich J, Behrendt H, Ring J, Wichmann HE, Illig T, Weidinger S: Loss-of function mutations in the filaggrin gene and allergic contact sensitization to nickel. J Invest Dermatol 2008;128:1430-1435.

68 Sergeant A, Campbell LE, Hull PR, Porter M, Palmer CN, Smith FJ, McLean WH, Munro CS Heterozygous null alleles in filaggrin contribute to clinical dry skin in young adults and the elderly. J Invest Dermatol 2009;129:1042-1045.

69 Ying S, Meng Q, Corrigan CJ, Lee TH: Lack of filaggrin expression in the human bronchial mucosa. J Allergy Clin Immunol 2006;118:1386-1388.

70 Palmer CN, Ismail T, Lee SP, Terron-Kwiatkowski A, Zhao Y, Liao H, Smith FJ, McLean WH, Mukhopadhyay S: Filaggrin null mutations are associated with increased asthma severity in children and young adults. J Allergy Clin Immunol 2007

71 Weidinger S, Illig T, Baurecht $\mathrm{H}$, et al: Loss-offunction variations within the filaggrin gene predispose for atopic dermatitis with allergic sensitizations. J Allergy Clin Immunol 2006;118:214-219.

72 McLean WH, Hull PR: Breach delivery: increased solute uptake points to a defective skin barrier in atopic dermatitis. J Invest Dermatol 2007;127:8-10.

73 Hudson TJ: Skin barrier function and allergic risk Nat Genet 2006;38:399-400.

-74 Weidinger S, Rodriguez E, Stahl C, Wagenpfeil S, Klopp N, Illig T, Novak N: Filaggrin mutations strongly predispose to early-onset and extrinsic atopic dermatitis. J Invest Dermatol 2007;127:724726.

75 Jungersted JM, Scheer H, Mempel M, Baurecht H, Cifuentes L, Hogh JK, Hellgren LI, Jemec GB, Agner T, Weidinger S: Stratum corneum lipids, skin barrier function and filaggrin mutations in patients with atopic eczema. Allergy 2010;65:911-918.
76 Kezic S, Kemperman PM, Koster ES, de Jongh CM, Thio HB, Campbell LE, Irvine AD, McLean WH, Puppels GJ, Caspers PJ: Loss-of-function mutations in the filaggrin gene lead to reduced level of natural moisturizing factor in the stratum corneum. J Invest Dermatol 2008;128:2117-2119.

77 Marenholz I, Kerscher T, Bauerfeind A, EsparzaGordillo J, Nickel R, Keil T, Lau S, Rohde K, Wahn $U$, Lee YA: An interaction between filaggrin mutations and early food sensitization improves the prediction of childhood asthma. J Allergy Clin Immunol 2009;123:911-916.

78 Schmitz A, Famulok M: Chemical biology: Ignore the nonsense. Nature 2007;447:42-43.

79 O'Regan GM, Sandilands A, McLean WH, Irvine $\mathrm{AD}$ : Filaggrin in atopic dermatitis. J Allergy Clin Immunol 2009;124:R2-6.

80 Novak N, Yu C, Bussmann C, Maintz L, Peng W, Hart J, Hagemann T, Diaz-Lacava A, Baurecht $\mathrm{H}$, Klopp N, Wagenpfeil S, Behrendt H, Bieber T, Ring J, Illig T, Weidinger S: Association of a TLR9 promoter polymorphism with atopic eczema. Allergy 2007;62:766-772.

81 Oh DY, Schumann RR, Hamann L, Neumann K, Worm M, Heine G: Association of the Toll-like receptor-2 A-16934t promoter polymorphism with severe atopic dermatitis. Allergy 2009;64:16081615.

82 He JQ, Chan-Yeung M, Becker AB, Dimich-Ward $\mathrm{H}$, Ferguson AC, Manfreda J, Watson WT, Sandford AJ: Genetic variants of the IL13 and IL4 genes and atopic diseases in at-risk children. Genes Immun 2003;4:385-389.

83 Hummelshoj T, Bodtger U, Datta P, Malling HJ, Oturai A, Poulsen LK, Ryder LP, Sorensen PS, Svejgaard E, Svejgaard A: Association between an interleukin-13 promoter polymorphism and atopy. Eur J Immunogenet 2003;30:355-359.

84 Tsunemi Y, Saeki H, Nakamura K, Sekiya T, Hirai K, Kakinuma T, Fujita H, Asano N, Tanida Y, Wakugawa M, Torii H, Tamaki K: Interleukin-13 gene polymorphism g4257a is associated with atopic dermatitis in Japanese patients. J Derm Sci 2002; 30:100-107.

85 Liu X, Nickel R, Beyer K, Wahn U, Ehrlich E, Freidhoff LR, Bjorksten B, Beaty TH, Huang SK: An IL13 coding region variant is associated with a high total serum IgE level and atopic dermatitis in the German multicenter atopy study (MAS-90). J Allergy Clin Immunol 2000;106:167-170.

86 Chang YT, Lee WR, Yu CW, Liu HN, Lin MW, Huang $\mathrm{CH}$, Chen CC, Lee DD, Wang WJ, $\mathrm{Hu} \mathrm{CH}$, Tsai SF: No association of cytokine gene polymorphisms in Chinese patients with atopic dermatitis. Clin Exp Dermatol 2006;31:419-423. 
87 Arshad SH, Karmaus W, Kurukulaaratchy R, Sadeghnejad A, Huebner M, Ewart S: Polymorphisms in the interleukin 13 and GATA binding protein 3 genes and the development of eczema during childhood. Br J Dermatol 2008;158:1315-1322.

-88 Liu Q, Xia Y, Zhang W, Li J, Wang P, Li H, Wei C, Gong Y: A functional polymorphism in the spink5 gene is associated with asthma in a Chinese Han population. BMC Med Genet 2009;10:59.

89 Walley AJ, Chavanas S, Moffatt MF, Esnouf RM, Ubhi B, Lawrence R, Wong K, Abecasis GR, Jones EY, Harper JI, Hovnanian A, Cookson WO: Gene polymorphism in Netherton and common atopic disease. Nat Genet 2001;29:175-178.

-90 Kato A, Fukai K, Oiso N, Hosomi N, Murakami T, Ishii M: Association of SPINK5 gene polymorphisms with atopic dermatitis in the Japanese population. Br J Dermatol 2003;48:665-669.

-91 Nishio Y, Noguchi E, Shibasaki M, Kamioka M, Ichikawa E, Ichikawa K, Umebayashi Y, Otsuka F, Arinami T: Association between polymorphisms in the SPINK5 gene and atopic dermatitis in the Japanese. Genes Immun 2003;4:515-517.

$\$ 92$ Weidinger S, Baurecht $\mathrm{H}$, Wagenpfeil S, et al: Analysis of the individual and aggregate genetic contributions of previously identified serine peptidase inhibitor Kazal type 5 (SPINK5), kallikreinrelated peptidase 7 (KLK7), and filaggrin (FLG) polymorphisms to eczema risk. J Allergy Clin Immunol 2008;122:560-568, e564.

$\checkmark 93$ Kabesch M, Carr D, Weiland SK, von Mutius E: Association between polymorphisms in serine protease inhibitor, Kazal type 5 and asthma phenotypes in a large German population sample. Clin Exp Allergy 2004;34:340-345.

-94 Jongepier H, Koppelman GH, Nolte IM, Bruinenberg M, Bleecker ER, Meyers DA, te Meerman GJ, Postma DS: Polymorphisms in SPINK5 are not associated with asthma in a Dutch population. J Allergy Clin Immunol 2005;115:486-492.

$\$ 95$ Hubiche T, Ged C, Benard A, Leaute-Labreze C, McElreavey K, de Verneuil H, Taieb A, Boralevi F: Analysis of SPINK5, KLK7 and FLG genotypes in a French atopic dermatitis cohort. Acta Derm Venereol 2007;87:499-505.

-96 Folster-Holst R, Stoll M, Koch WA, Hampe J, Christophers E, Schreiber S: Lack of association of SPINK5 polymorphisms with nonsyndromic atopic dermatitis in the population of northern Germany. Br J Dermatol 2005;152:1365-1367.

-97 Mao XQ, Shirakawa T, Yoshikawa T, Yoshikawa K, Kawai M, Sasaki S, Enomoto T, Hashimoto T, Furuyama J, Hopkin JM, Morimoto K: Association between genetic variants of mast-cell chymase and eczema. Lancet 1996;348:581-583.
98 Mao XQ, Shirakawa T, Enomoto T, Shimazu S, Dake Y, Kitano H, Hagihara A, Hopkin JM: Association between variants of mast cell chymase gene and serum ige levels in eczema. Hum Hered 1998;48:3841.

99 Tanaka K, Sugiura H, Uehara M, Sato H, HashimotoTamaoki T, Furuyama J: Association between mast cell chymase genotype and atopic eczema: comparison between patients with atopic eczema alone and those with atopic eczema and atopic respiratory disease. Clin Exp Allergy 1999;29:800-803.

100 Weidinger S, Rummler L, Klopp N, Wagenpfeil S, Baurecht HJ, Fischer G, Holle R, Gauger A, Schafer T, Jakob T, Ollert M, Behrendt H, Wichmann HE, Ring J, Illig T: Association study of mast cell chymase polymorphisms with atopy. Allergy 2005;60: 1256-1261.

101 Kawashima T, Noguchi E, Arinami T, Kobayashi K, Otsuka F, Hamaguchi H: No evidence for an association between a variant of the mast cell chymase gene and atopic dermatitis based on case-control and haplotype-relative-risk analyses. Hum Hered 1998;48:271-274.

102 Hosomi N, Fukai K, Oiso N, Kato A, Ishii M, Kunimoto H, Nakajima K: Polymorphisms in the promoter of the interleukin-4 receptor alpha chain gene are associated with atopic dermatitis in Japan. J Invest Dermatol 2004;122:843-845.

103 Oiso N, Fukai K, Ishii M: Interleukin 4 receptor alpha chain polymorphism gln551arg is associated with adult atopic dermatitis in Japan. Br J Dermatol 2000;142:1003-1006.

104 Callard RE, Hamvas R, Chatterton C, Blanco C, Pembrey M, Jones R, Sherriff A, Henderson J: An interaction between the IL-4r-alpha gene and infection is associated with atopic eczema in young children. Clin Exp Allergy 2002;32:990-993.

105 Tanaka K, Sugiura H, Uehara M, Hashimoto Y, Donnelly C, Montgomery DS: Lack of association between atopic eczema and the genetic variants of interleukin- 4 and the interleukin-4 receptor alpha chain gene: heterogeneity of genetic backgrounds on immunoglobulin e production in atopic eczema patients. Clin Exp Allergy 2001;31:1522-1527.

106 Weidinger S, Klopp N, Rummler L, Wagenpfeil S, Novak N, Baurecht HJ, Groer W, Darsow U, Heinrich J, Gauger A, Schafer T, Jakob T, Behrendt H, Wichmann HE, Ring J, Illig T: Association of NOD1 polymorphisms with atopic eczema and related phenotypes. J Allergy Clin Immunol 2005; 116:177-184.

107 Macaluso F, Nothnagel M, Parwez Q, PetraschParwez E, Bechara FG, Epplen JT, Hoffjan S: Polymorphisms in NACHT-LRR (NLR) genes in atopic dermatitis. Exp Dermatol 2007;16:692-698. 
108 Nickel R, Casolaro V, Wahn U, Beyer K, Barnes KC Plunkett B, Freidhoff LR, Sengler C, Plitt J, Schleimer RP, Caraballo L, Naidu RN, Beaty T, Huang SK: Atopic dermatitis is associated with a functional mutation in the promoter of the CC chemokine RANTES. J Immunol 2000;164:1612-1616.

109 Bai B, Tanaka K, Tazawa T, Yamamoto N, Sugiura $\mathrm{H}$ : Association between rantes promoter polymorphism-401a and enhanced RANTES production in atopic dermatitis patients. J Dermatol Sci 2005;39:189-191.

Michael Kabesch, MD

Center for Pediatrics, Clinic for Pediatric Pneumology

Allergy and Neonatology, Hannover Medical School

Carl-Neuberg-Strasse 1

DE-30625 Hannover (Germany)

Tel. +49511532 3325, E-Mail Kabesch.Michael@mh-hannover.de
110 Tanaka K, Roberts MH, Yamamoto N, Sugiura H, Uehara M, Hopkin JM: Upregulating promoter polymorphisms of RANTES relate to atopic dermatitis. Int J Immunogenet 2006;33:423-428.

111 Kozma GT, Falus A, Bojszko A, Krikovszky D, Szabo T, Nagy A, Szalai C: Lack of association between atopic eczema/dermatitis syndrome and polymorphisms in the promoter region of RANTES and regulatory region of MCP-1. Allergy 2002;57:160163.

112 O’Regan GM, Sandilands A, McLean WH, Irvine AD. Filaggrin in atopic dermatitis. J Allergy Clin Immunol 2008;122:689-693. 